\title{
GCU
}

Glasgow Caledonian

University

University for the Common Good

\section{Debate: redefining the role of the state}

McTavish, Duncan

Published in:

Public Money and Management

DOI:

10.1080/09540962.2016.1266140

Publication date:

2017

Document Version

Author accepted manuscript

Link to publication in ResearchOnline

Citation for published version (Harvard):

McTavish, D 2017, 'Debate: redefining the role of the state', Public Money and Management, vol. 37, no. 2, pp. 76-78. https://doi.org/10.1080/09540962.2016.1266140

\section{General rights}

Copyright and moral rights for the publications made accessible in the public portal are retained by the authors and/or other copyright owners and it is a condition of accessing publications that users recognise and abide by the legal requirements associated with these rights.

Take down policy

If you believe that this document breaches copyright please view our takedown policy at https://edshare.gcu.ac.uk/id/eprint/5179 for details of how to contact us. 


\section{Redrawing the Boundaries of the Third Sector and Civil Society in Troubled Times Debate article, Public Money and Management, Vol. 37, 2017 Duncan McTavish}

There have been three broad boundary definitions explaining the borders of the state, third sector and civil society in the UK in the last 100 years or so. First is the pre 1930s (relatively) small state, albeit substantially increased by military expenditures up to and through two world wars, but with a limited if growing range of social and welfare provision: the space thus existing was occupied by the voluntary and charitable sector, philanthropy and civil society outwith the state. In some UK cities major healthcare and hospital provision was provided by this sector, sometimes in association with local authorities and overseen by Boards, Guardians and others, pretty much independent of the state and often funded locally. Second has been the post 1940s social investment and welfare provision underwritten by the state and largely delivered through central and local government institutions. This led to the nationalisation and growth of services with civil society's and third sector's roles delimited within the 'welfare state'. Many of these boundaries still exist but have been modified, with attempts at re-drawing them from the 1980s. Since then there has been the decline of Keynesian state led economic management largely led by Conservative governments, giving public priority to market led approaches; the notion of a re-calibrated relationship between public and private sectors, state and civil society (the 'third way', driven by New Labour governments); more recently the post financial crash era of 'austerity' which has led to a reimagining of the size and role of the state particularly in the area of service provision the position of third sector and civil society in this altered landscape. Conversely there has been very little reduction of the state in terms of its military or strategic capacity or in its reach over citizens. So there is an interesting debate on the boundaries of the state, third sector and civil society, especially when considering service provision. Arguably these boundaries have been shifting since the 1980s, but the debate is particularly focused in the current era of sustained pressure on public finances which underpin the boundaries.

The strands of the debate are best understood in the context of definitions and understandings of the role of the state, and how each of these create space (or choke off space) for the third sector and civil society. It should of course be noted that these conceptions of the state are not mutually exclusive or discrete and actual practice and policies of governments may resemble hybridised approaches.

The oversight state is one which meta-governs delivery, as distinct from direct state provision. In many senses this captures the governance environment where government activities and service delivery are carried out by a wide range of agents and organisations, public, quasi public, mutualised, private, third sector. This approach had much currency during New Labour's years in power, where the message often was that 'what matters is what works', and provided a range of outputs and outcomes were delivered there was little attention paid to who was delivering. Third sector bodies could be, and often were / are included in the delivery mix through community based organisations, social enterprises and so on.

The competition state is one which crafts policies designed to make the economy competitive, often considered business friendly and involving deregulation. Third sector bodies and civil society organisations have sometimes found a space to operate here by accessing individuals in communities and neighbourhoods into jobs and skills training 
initiatives to enhance capacity building thereby easing inclusion into competitive local and national economies. 'Civic entrepreneurs' too have operated successfully in this space.

The stand-off state is one which wishes to draw back from intervention, for fiscal or politicalideological motives. Yet despite reluctance to intervene, such a state may well be pliable in the face of political pressure from communities, thereby giving an important locus for third sector and civil society involvement. There are many examples of success (and failure too) ranging from the local campaigns to save important community or local assets to a broader normative understanding of the importance of communities taking action to make their collective voice heard (Alinsky 1971).

Finally, there are rawer ideological conceptions of the state: that is a belief that the state should be rolled back in principle. This conception can be nuanced. A belief in the primacy of the individual and individualism would tend to support individual rather than organisational initiative, therefore have less of a role for third sector, civil society or other forms of organisational or collective endeavour. On the other hand there is a body of thinking which sees communities as alternatives to state action, with individuals and their communities working together outwith the control and direction of the state (see e.g. Blond 2010). This can put the third sector and civil society as leading actors. 'The Big Society' much talked about after the Conservative led coalition government took power in 2010 was founded on such thinking (see Open Public Services 2011), though (to put it mildly) this seems to have been lost from the political agenda, leaving state roll back as an end in itself or at best rather lop sided without a balancing of third sector, civil society or 'big society' alongside.

Yet it is well recognised, with research to back this up, that whatever the configuration of boundaries, third sector bodies can be very responsive (reaching individuals and communities which central state and local government cannot) as well as resilient, as shown by one of the contributions in this issue. But beyond the small scale and localised initiatives, it is clear that changed configuration of state and service provision tends to favour large private sector organisations - e.g. another of the papers in this special issue shows the Health and Social Care Act, operational in the NHS in England since 2013, has resulted in non NHS providers able to win NHS funded contracts, with three times more of these contracts going to private sector rather than third sector providers. This of course is hardly surprising, given in general the much stronger resource and capacity base of the former. Real and meaningful boundary change between state, third sector and civil society is unlikely to occur simply because such bodies exist, do useful work and can serve individuals and communities well. Without legislative guarantee and control of their own assets, even large third sector bodies may be subject to state direction: witness the government's policy (in England) obliging Housing Associations (among whom are some of the largest and most powerful third sector organisations around) to sell properties at large discount to sitting tenants, a policy many of these Associations do not support.

To conclude, the boundaries between state, third sector and civil society have shifted and are dependent on conceptions on the role of the state but are defined very much by the state. The key to a permanent and settled power and boundary shift between state and third sector, to give greater salience to the latter, lies in

(a) recognition of the social and public value of approaches which give individuals and communities greater control over the assets which impact on day to day living, delivery of services for a modern twenty first century society targeted at community and individual 
health and well being; there is growing evidence of the positive relationship between community centred approaches seeking to mobilise assets within communities, increasing people's control over their lives and positive health and well being outcomes (https://www.gov.uk/government/uploads/system/uploads/attachment_data/file/402889/A_gu ide_to_community-centred_approaches_for_health_and_wellbeing_briefi__.pdf)

(b) sustained public policy commitment to (a). There have been some tentative steps in this direction, for example through the Scottish Government's community land ownership, and more recently community based asset (CBA) approaches to community development (http://www.gov.scot/Topics/People/engage/CommunityAssetOwnership) - but some argue this is as yet too small scale and lacking in ambition. It should also be recognised that there are institutional and environmental challenges to be addressed before such approaches become mainstream. For example, there may be resistance from existing public service providers like local government who perceive a challenge to their traditional role (e.g., see https://www.jrf.org.uk/report/community-organisations-controlling-assets-better-

understanding); there is no cross UK comparability study of CBA initiatives or the potential of such - indeed after an apparent rush of enthusiasm for 'Big Society' initiatives, as an alternative to state led approaches to policy and service delivery, in the early stages of the UK Conservative led coalition government in 2010, 'big societies' and 'empowered communities' seem now to have little policy or political salience at UK Government level: here the current policy narrative seems to be about a drive towards a smaller state. Where does this leave society and communities? Clearly, if policy makers - that is to say those in charge of the state machine - consider normatively that communities and individuals should be able to exert control over their lives, then this gives a real opportunity to fundamentally redraw the boundaries between the state, the third sector and civil society.

Professor Duncan McTavish, Glasgow Caledonian University

References

Alinsky, S. (1971) Rules for Radicals. Vintage Books

Blond, P. (2010) Red Tory: How Left and Right Have Broken Britain and How We Can Fix It. London. Faber.

Open Public Services White Paper 2011, Cmnd. 8145. 